\title{
Geologia, petrografia e geocronologia das rochas do depósito aurífero Ouro Roxo, Província Tapajós, Jacareacanga (PA), Brasil
}

\author{
Geology, petrography and geocronology of the Ouro Roxo gold \\ deposit rocks, Tapajós Province, Jacareacanga (PA), Brazil
}

\author{
Ângela Suélem Rocha Veloso*, Márcio Dias Santos
}

\begin{abstract}
RESUMO: O depósito Ouro Roxo localiza-se próximo da cidade de Jacareacanga, Província Aurífera Tapajós, sudoeste do Pará. O depósito consiste em um sistema hidrotermal de veios de quartzo sulfetados, hospedado em granitoides paleoproterozoicos milonitizados da Suíte Intrusiva Tropas e controlado estruturalmente pela zona de cisalhamento N-S Ouro Roxo-Canta Galo (ZCOC). Os granitoides hospedeiros são granodioritos e tonalitos oxidados, calcioalcalinos, típicos de arco magmático. A ZCOC é oblíqua sinistral dúctil-rúptil e enquadra-se no terceiro evento de deformaçáo da Província Tapajós que transformou os granitoides Tropas em protomilonitos e milonitos intercalados com brechas. A foliaçấo milonítica NNE mergulhando para ESSE e uma lineação de estiramento em gráos de quartzo indicam a direçáo do movimento para NW. Filóes e corpos tubulares de quartzo mineralizados ocorrem encaixados nos milonitos e brechas, envolvidos por halos de alteração hidrotermal. Além da silicificaçáo e sulfetaçấo concentradas nos corpos mineralizados, três tipos de alteração hidrotermal ocorrem: propilitização (clorita + fengita + carbonato); alteraçáo filica (fengita + quartzo + carbonato + pirita); carbonatação. Além do quartzo magmático e do quartzo microcristalino dos milonitos, foram reconhecidas cinco geraçōes de quartzo hidrotermal nos filōes, estando o minério relacionado ao quartzo4. Os dados isotópicos $\mathrm{Pb}-\mathrm{Pb}$ não sustentam uma relaçăo genética entre o depósito aurífero e os granitoides Tropas, sendo o depósito contemporâneo à granitogênese Maloquinha. $\mathrm{O}$ ambiente orogênico, o estilo filoneano do depósito, o controle estrutural, a alteração hidrotermal (propilítica + filica + carbonatação) e a associaçấo metálica $(\mathrm{Au}+\mathrm{Cu}+\mathrm{Bi})$ são compatíveis com o modelo orogênico da interface mesozona-epizona para a gênese do depósito aurífero Ouro Roxo.
\end{abstract}

PALAVRAS-CHAVES: Província Tapajós; cisalhamento; Ouro Roxo.

\begin{abstract}
The Ouro Roxo gold deposit lies near the city of Jacareacanga, Tapajós Gold Province, southwestern of Pará, Brazil. The Ouro Roxo deposit comprises a hydrothermal system of sulfide quartz veins hosted by mylonite granitoid Tropas Intrusive Suit of Paleoproterozoic age and controlled by the N-S trending Ouro Roxo-Canta Galo shear zone (OCSZ). The host granitoids are oxidized calc-alkaline granodiorite and tonalite of magmatic arc filiation. The OCSZ is a sinistral oblique ductile-brittle shear, which belongs to the third deformation event of the Tapajós Province and has turned the granitoids into protomylonites, mylonites and breccias. The NNE-SSW mylonitic foliation dipping to ESE and stretch lineation in quartz grains indicate the tectonic movement to NW. Mineralized quartz veins and pipes are hosted by mylonites and breccias and surrounded by hydrothermal alteration halos. Besides silicification and sulfidation, concentrated in the ore bodies, three types of wall-rock alteration occur: propilitization (chlorite + phengite + carbonate); phylic alteration (phengite + quartz + carbonate + pyrite); carbonatization. Besides magmatic quartz and microcrystalline quartz of mylonites, five generations of hydrothermal quartz were recognized in the lodes. The isotopic $\mathrm{Pb}-\mathrm{Pb}$ data do not support a genetic relationship between the gold deposit and the Tropas granitoids, being the deposit coeval to Maloquinha granite. The orogenic environment, the veining style, the structural control, the hydrothermal alteration and the metallic association $(A u+C u+B i)$, are all consistent with a mesozona-epizona orogenic model for the genisis of the Ouro Roxo deposit.
\end{abstract}

KEYWORDS: Tapajós Province; shearing; Ouro Roxo.

Programa de Pós-graduação em Geologia e Geoquímica, Instituto de Geociências, Universidade Federal do Pará - UFPA, Belém (PA), Brasil. E-mails: angelasveloso@usp.br,mds@ufpa.br

*Autor correspondente

Manuscrito ID 27618. Recebido em: 14/06/2012. Aprovado em: 28/10/2012 


\section{INTRODUÇÃO}

A Província Aurífera Tapajós (PAT), entre as cidades de Jacareacanga, Itaituba, Novo Progresso e Castelo dos Sonhos, sudoeste do estado do Pará, foi a região que mais produziu ouro no país nas 3 últimas décadas do século passado, cuja produção anual atingiu 60 a 80 t entre 1975 e 1990 (Santos et al. 2001). A lavra do ouro neste período ocorreu exclusivamente por meio da atividade garimpeira, principalmente em depósitos aluvionares e coluvionares. A baixa tonelagem dos depósitos residuais não permitiu vida longa para este ciclo que começou a declinar nos anos 1990, abrindo perspectiva para mineração empresarial voltada principalmente para os depósitos primários, com maior reserva e exigindo técnicas de explotação mais complexas e onerosas e, até entâo, pouco conhecidos. A partir da década de 1990, a região do Tapajós tem sido alvo de trabalhos geológicos sistemáticos, tanto de mapeamento básico, realizados pelo Serviço Geológico do Brasil (CPRM) (Faraco, Carvalho \& Klein 1997, Almeida et al. 2000, Klein \& Vasques 2000, Bahia \& Quadros 2000, Ferreira et al. 2000, Vasques \& Klein 2000), como também de exploração mineral por diversas empresas de mineração. Uma classificação genética preliminar para os depósitos auríferos da Província Tapajós foi proposta por Santos et al. (2001), em dois tipos: 1) orogênico mesozonal, hospedados em turbiditos ou em granitoides de arco magmático; e 2) relacionado à intrusão, tanto filoneano como disseminado (similar ao tipo porfirítico). Um terceiro tipo, considerado como epitermal proterozoico, foi proposto por Dreher, Vlach \& Martini (1998), Jacob (1999), Juliani et al. (2005) para alguns depósitos classificados por Santos et al. (2001) como relacionado à intrusão filoneano.

O depósito Ouro Roxo, objeto do presente trabalho, é um dos mais importantes depósitos auríferos da PAT e está localizado no município de Jacareacanga, região de Vila Porto Rico, às margens do rio Pacu, na parte centro-oeste da PAT (Fig. 1). Os direitos minerários do alvo Ouro Roxo estão em posse atualmente da Amazon Mineral Explorers. Este depósito foi classificado por Santos et al. (2001) como orogênico mesozonal, mas dados de detalhe sobre o controle estrutural, relação espacial e temporal com os granitoides hospedeiros e sobre os fluidos mineralizantes, não foram apresentados. O trabalho no depósito Ouro Roxo foi realizado para aumentar o grau de conhecimento do depósito, por meio de dados integrados de geologia, petrografia e geocronologia, com o objetivo de esclarecer a correlação entre o incremento da deformação cisalhante, que gerou milonitos e brechas, e a formação de veios mineralizados, a partir de um protólito granodiorítico em uma zona de cisalhamento, e se a mineralização tem alguma relação genética com as rochas graníticas hospedeiras.

\section{CONTEXTO GEOLÓGICO REGIONAL}

A província aurífera do Tapajós (Fig. 1) está localizada na porção centro-sul do cráton Amazônico e faz parte de uma unidade geotectônica maior denominada cinturão orogênico Tapajós-Parima (Santos et al. 2000) ou província Ventuari-Tapajós (Tassinari \& Macambira 1999), de idade paleoproterozoica, que atravessa o cráton Amazônico de NW a SE. O cinturão orogênico Tapajós-Parima é um orógeno acrescionário do tipo andino, no qual uma crosta oceânica (a oeste) colidiu com um continente (a leste). A província aurífera do Tapajós corresponde aproximadamente ao domínio Tapajós do cinturão Tapajós-Parima, limitada ao norte pela sinéclise do Amazonas, a leste pela província Amazônia Central, a oeste pela província Rondônia-Juruena e ao sul pelo domínio Alta Floresta do cinturão Tapajós-Parima.

Até a década de 1970, grande parte das unidades litológicas da regiáo do Tapajós estava reunida no Complexo Xingu como embasamento indiferenciado (Santos et al. 1975). O detalhamento dos trabalhos na região, iniciado por Bizinella et al. (1980), permitiu individualizar, no lugar do Complexo Xingu, uma sequência supracrustal vulcano-sedimentar denominada Grupo Jacareacanga, duas suítes de granitoides calcioalcalinos, conhecidas como Complexo Cuiú-Cuiú e Suíte Intrusiva Parauarí, e uma suíte máfica, denominada Suíte Intrusiva Ingarana (Fig. 1). Posteriormente, Ricci et al. (1999) e Santos et al. (2001) definiram, respectivamente, a Suíte Intrusiva Creporizão e a Suíte Intrusiva Tropas (Fig. 1), ambas de granitoides calcioalcalinos. O Grupo Jacareacanga e o Complexo Cuiú-Cuiú são de idade riaciana/orosiriana $(>2,0 \mathrm{Ga})$, enquanto que as outras unidades, predominantemente de granitoides, são de idade orosiriana $(2,0$ a 1,8 Ga) do período paleoproterozoico. Além disso, as características geológicas e metalogenéticas da região do Tapajós levaram Faraco, Carvalho \& Klein (1997) a definir aquela região como Província Aurífera do Tapajós (PAT), de idade paleoproterozoica.

Klein et al. (2002) reconheceram três eventos de deformação na PAT. O primeiro evento (D1) é caracterizado por falhas e zonas de cisalhamento rúptil-dúctil subverticais de direção NNW-SSE que afetaram as rochas do Grupo Jacareacanga e Complexo Cuiú-Cuiú, entre 2005 e $1997 \mathrm{Ma}$, que exibem foliação e eixos de dobras isoclinais na direção NNW-SSE. O segundo evento (D2) é marcado por um sistema de falhas transcorrentes de direção NWSE que afetou o Complexo Cuiú-Cuiú e a Suíte Intrusiva Creporizão entre 1,97 e 1,95 Ga. Esses lineamentos NNW-SSE e NW-SE são as estruturas mais proeminentes na PAT e foram interpretados como resultantes de um 


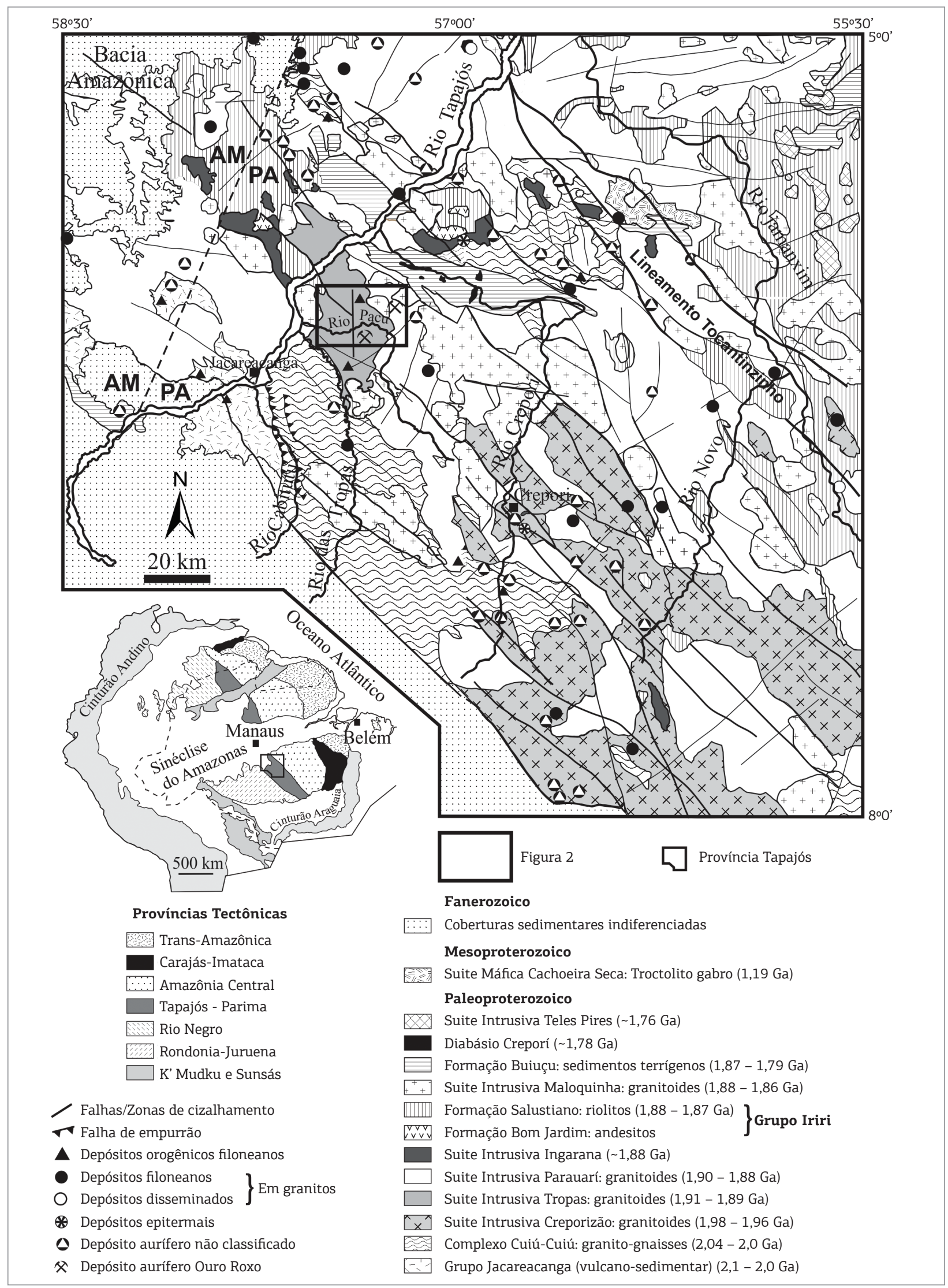

Figura 1. Mapa geológico da Província Tapajós, mostrando a área estudada e localização da província no cráton Amazônico e na América do Sul. Adaptado de Almeida et al. (2000), Bahia \& Quadros (2000), Ferreira et al. (2000), Klein \& Vasquez (2000), Vasquez \& Klein (2000) e Santos et al. (2006). 
evento compressivo progressivo com $\sigma_{1}$ em torno da direção E-W. O terceiro evento (D3) corresponde a zonas de cisalhamento dúctil-rúptil transcorrente sinistral de direção média N-S, que afetaram as rochas das Suítes Creporizão e Tropas e parcialmente as rochas da Suíte Parauari, entre 1894 e 1883 Ma. Eventos deformacionais mais jovens que D3 são eminentemente rúpteis, gerados durante a colocação dos plútons graníticos da Suíte Maloquinha e relacionados à tectônica extensional (Klein et al. 2002).

Santos et al. (2004) reconheceram duas orogêneses distintas na província Tapajós. A primeira, denominada orogênese Mundurucus (2,04 a 1,96 Ga), iniciouse com a formação do arco de ilhas primitivo Cuiú-Cuiú $(2,04$ a 2,0 Ga), seguido da formação dos arcos magmáticos continentais Jamanxim (2,0 Ga) e Creporizão (1,98 a $1,96 \mathrm{Ga}$ ). Após um hiato de aproximadamente $50 \mathrm{Ma}$, começou a segunda orogênese, denominada Tropas, que também iniciou com a formação de um arco de ilhas primitivo (arco Tropas) entre 1,90 e 1,89 Ga, seguido da formação do arco magmático continental Parauari $(1,89$ a 1,88 Ga). Por outro lado, Vasquez, Klein \& Ricci (2001) consideraram que houve apenas uma orogênese (Cuiú-Cuiú) seguida de granitoides pós-colisionais (Creporizão, Tropas e Parauari). Os eventos acrescionários foram seguidos por um evento magmático vulcano-plutônico alcalino, intracratônico, tardio a pós-tectônico entre 1,88 a 1,86 Ga (Grupo Iriri e suíte Maloquinha), relacionado com fusão parcial da crosta arqueana do cráton Amazônico.
Atividades magmáticas e sedimentares intracratônicas póstectônicas ou anorogênicas, relacionadas com rifteamento da crosta, ocorreram no final do período Orosiriano e início do Estateriano, tais como a Formação Buiuçu (1,87 a 1,79 Ga), Diabásio Crepori ( 1,78 Ga), Granito rapakivi Teles Pires $(\sim 1,76 \mathrm{Ga})$ e, já no mesoproterozoico, os álcali basaltos da Suíte Cachoeira Seca $(\sim 1,19 \mathrm{Ga})$.

\section{GEOLOGIA DA REGIÃO DO DEPÓSITO OURO ROXO}

Predominam na região das vilas Porto Rico e São José rochas graníticas calcioalcalinas anteriormente incluídas na Suíte Intrusiva Parauari que ocorrem no baixo curso dos rios das Tropas e Pacu, estendendo-se a norte do rio Tapajós, na porção centro-oeste da província Tapajós. A Maior parte destas rochas graníticas foi incluída por Santos et al. (2001) na Suíte Intrusiva Tropas, pouco mais antiga que a suíte Parauari (Fig. 2). Na parte leste dessa área ocorrem rochas graníticas calcioalcalinas, de composição sieno a monzogranítica, mantidos na suíte intrusiva Parauari e que fazem parte de um corpo batolítico alongado na direção NW-SE, normalmente isotrópico e localmente com foliação protomilonítica. Stocks graníticos isotrópicos, sem evidência de deformação, de composição álcali a sienogranítica, da suíte intrusiva Maloquinha, cortam os granitos Parauari e Tropas na área estudada, dois na parte leste da área e um terceiro stock no extremo oeste da área.

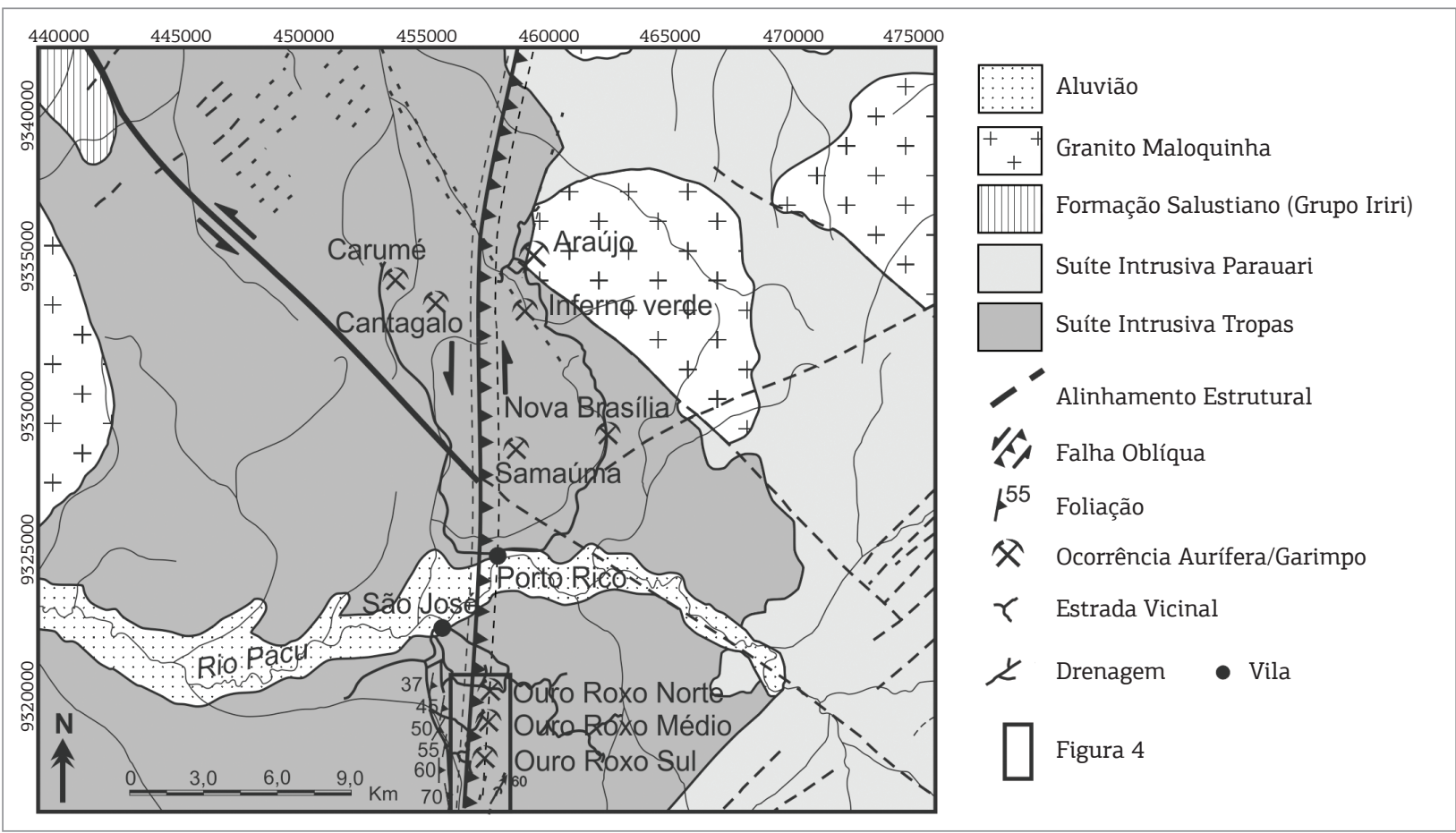

Figura 2. Mapa geológico da região da vila Porto Rico, mostrando a zona de cisalhamento Ouro Roxo-Canta Galo e os alvos auríferos, com destaque para os três setores do depósito Ouro Roxo (Norte, Médio e Sul). Modificado de Souza (2007). 
A Suíte Intrusiva Tropas, na região do depósito Ouro Roxo, é constituída por metagranitoides mesocráticos de composição granodiorítica, tonalítica a diorítica. Normalmente são porfiríticos e isotrópicos, mas exibem uma sutil orientação protomilonítica nas porçôes afetadas pelo cisalhamento (Fig. 3A), definida pela orientação de minerais micáceos, o que empresta à rocha uma textura lepidoblástica local (Fig. 3B). Ferreira et al. (2000) descreveram também nesta unidade monzogranitos, quatzo dioritos, andesitos e basaltos calcioalcalinos, com xenólitos de metabasaltos e meta-andesitos do Complexo CuiúCuiú e da suíte Creporizão, não observados na área estudada onde predominam os metagranodioritos porfiríticos. Essas rochas são constituídas por fenocristais de plagioclásio de composição $\mathrm{An}_{30-40}$ (andesina) e feldspato potássico (microclina) envolvidos por uma matriz média a fina de plagioclásio, feldspato potássico, quartzo, hornblenda e biotita (Fig. 3C). Como minerais acessórios ocorrem allanita, titanita, zircáo e opacos (magnetita e pirita) e, como minerais secundários, clorita, sericita e carbonato (Fig. 3D). Santos et al. (2004) obtiveram, pelo método U-Pb TIMS em zircão e titanita, idades de $1893 \pm 3$ Ma para o metatonalito hospedeiro do depósito Ouro Roxo (metatonalito Ouro Roxo), na regiáo do rio Pacu, e idades entre $1897 \pm 3$ e $1894 \pm 3$ Ma para o tonalito Tropas, mais ao sul, no baixo curso do rio das Tropas.

\section{Zona de cisalhamento Ouro Roxo- Canta Galo}

As rochas graníticas da suíte Tropas, na região das vilas Porto Rico e São José, foram afetadas por uma zona de cisalhamento, denominada Ouro Roxo-Cantagalo (ZCOC), cuja falha principal estende-se por aproximadamente $20 \mathrm{~km}$ na direção N-S com $500 \mathrm{~m}$ a $1 \mathrm{~km}$ de

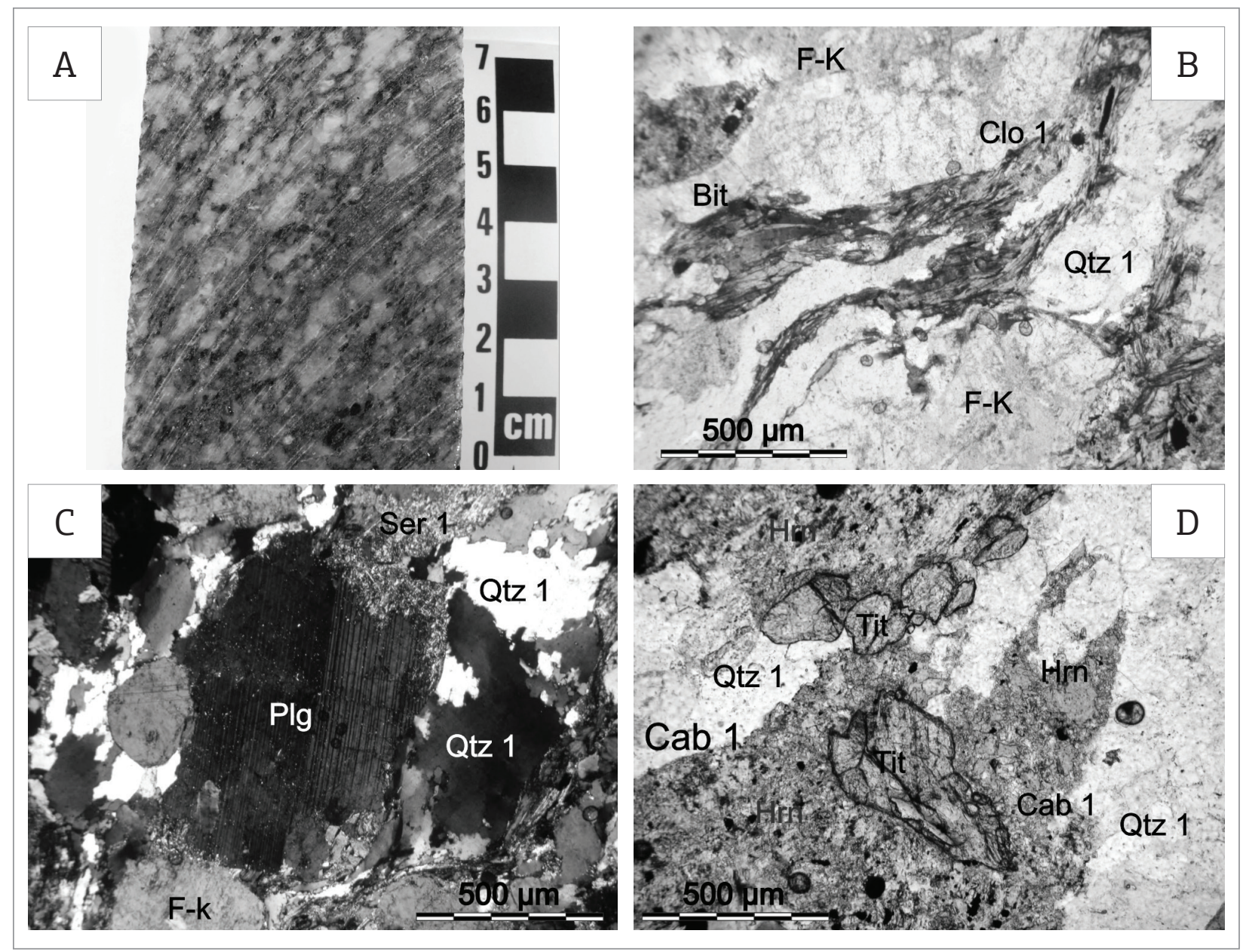

Figura 3. Fotografias do protólito granodiorítico da Suíte Intrusiva Tropas. (A) Testemunho de sondagem de metagranodiorito porfirítico com orientação protomilonítica. (B) Fotomicrografia mostrado foliação incipiente definida pela orientação de biotita (Bit) e clorita (Clo). (C) Fotomicrografia de fenocristal de plagioclásio (Plg) alterado para sericita (Ser). (D) Fotomicrografia mostrando cristais de titanita (Tit) associados com hornblenda (Horn), magnetita (Mgt) e carbonato (Cab). 
largura, na região do rio Pacu (Fig. 4A). A ZCOC enquadra-se no terceiro evento de deformação (D3) da Província Tapajós (Klein et al. 2002) e sua falha principal é predominantemente transcorrente sinistral, com uma componente de empurrão e profundidade intermediária, a qual pode ser classificada como falha oblíqua de rejeito direcional e de mergulho (Park 1988). A zona de cisalhamento é caracterizada por uma sequência de milonitos e brechas que se intercalam em camadas e lentes métricas a decamétricas e envolvem porçóes mais preservadas de granitoides (pods), com predomínio das brechas na área do depósito norte (Fig. 4B) e maior participaçáo dos milonitos na parte sul (Fig. 4C), indicando que o regime foi mais profundo ao sul. A intercalação de milonitos e brechas, com proporçôes variáveis das duas litologias, indica que o processo foi progressivo e ocorreu na zona de transição dúctil-rúptil. Além de deformada, essa sequência encontra-se também hidrotermalmente alterada e mineralizada (Veloso et al. 2008, Veloso 2011).

Os milonitos da zona de cisalhamento, na área do depósito Ouro Roxo, apresentam foliação com atitude N10$20 \mathrm{E}$ e mergulhos em torno de $20^{\circ}$ (Ouro Roxo Sul) a $40^{\circ}$ (Ouro Roxo Norte) para SE, diferente da estruturaçáo regional dos metagranitoides da Suíte Tropas que exibem atitudes da foliação e bandamento com direção aproximadamente N-S e mergulhos de médio a alto ângulo $\left(60-90^{\circ}\right)$ para E. Uma proeminente lineação, representada pelo estiramento do quartzo magmático em torno da direção N20W, de difícil reconhecimento nos afloramentos muito alterados, porém muito evidente nos testemunhos de sondagem,

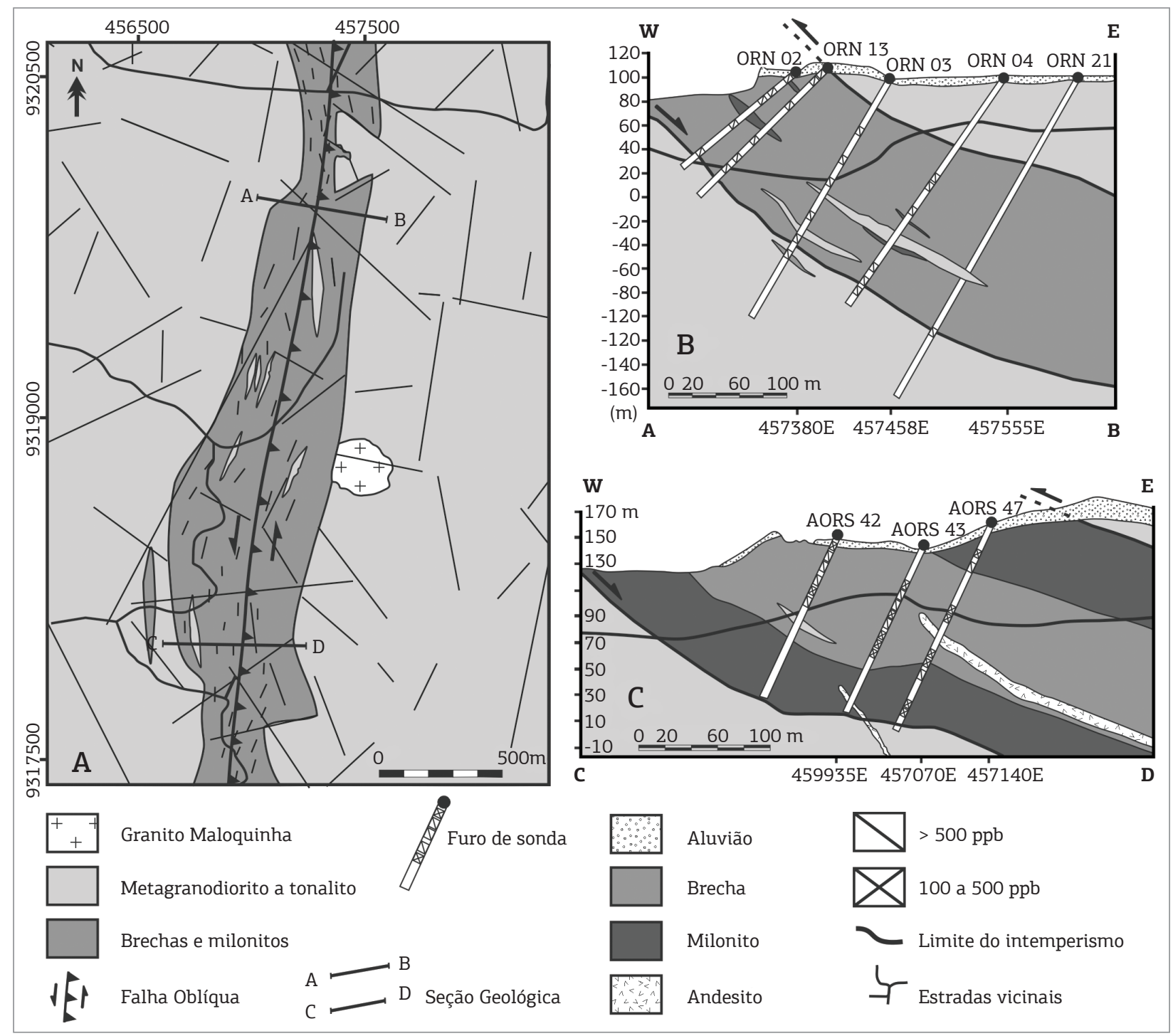

Figura 4. Mapa geológico de detalhe da região do depósito Ouro Roxo (A), mostrando a zona de cisalhamento Ouro Roxo-Canta Galo e duas seções geológicas, uma no Ouro Roxo Norte (B) e outra no Ouro Roxo Sul (C), modificado de Souza (2007). 
revela a direção do movimento tectônico oblíquo para NW, com rejeito direcional e de mergulho. A sinuosidade dos planos da falha, onde ocorreu o movimento oblíquo, além de controlar o alojamento dos corpos mineralizados, também condicionou a canalização dos fluidos mineralizantes e a deposição do minério em armadilhas estruturais (sítios de transtensão) em corpos filonianos e tubulares ao longo do plano principal do cisalhamento (Fig. 5).

Os termos dúcteis desta sequência variam desde protomilonitos até ultramilonitos. Os protomilonitos caracterizam-se pela granulação média a grossa e pouca matriz em relaçáo aos porfiroclastos de plagioclásio e de feldspato potássico. As principais feições de cisalhamento nestas rochas são deslocamento e rotação de fragmentos por fraturas de cisalhamento, registradas nos cristais de plagioclásio, e uma discreta foliação definida pelos minerais micáceos (fengita e clorita) e quartzo microcristalinos. A transformação dos protomilonitos em milonitos é acompanhada por uma diminuição no volume modal e no tamanho dos porfiroclastos de plagioclásio e de feldspato potássico e por um aumento na proporçáo matricial da rocha, de acordo com as definiçóes de Sibson (1977). Nos milonitos do depósito Ouro Roxo, o efeito da deformação produziu elementos de transformação registrados principalmente nos filossilicatos, tais como intercrescimento epitaxial dos feixes orientados de mica branca (fengita), definindo os planos $\mathrm{C}$ do cisalhamento (Figs. 6A e B), pela formação de mica-fish (Fig. 6C) e também pela transformação dos porfiroclastos de plagioclásio em feiçóes amendoadas com calda de recristalização, seguido de sombra de pressão com cinemática sinistral (Fig. 6D). Destacam-se ainda feiçôes de microboudinagem desenvolvida nos cristais de plagioclásio que também demarcam a foliação milonítica (Fig. 6E) e microfalhas seguidas de deslocamento e rotação/distensão observadas nos cristais plagioclásio (Fig. 6F).
O reconhecimento de ultramilonitos na área do depósito Ouro Roxo, embora de ocorrência localizada, indica que o cisalhamento foi profundo, alcançando condiçóes plenamente dúcteis. Essas rochas se caracterizam pelo aumento considerável da matriz na rocha, composta por mica branca, clorita e quartzo recristalizado, em relação à quantidade de porfiroclastos reliquiares de plagioclásio e feldspato potássico, conforme as definiçóes de Sibson (1977). Como consequência do processo de ultramilonitização, a orientaçáo dos minerais micáceos tende a se paralelizar com as bordas da zona de cisalhamento. A granulaçáo fina dos ultramilonitos e a escassez de porfiroclastos confundem estas rochas com aquelas do halo de alteração hidrotermal do depósito.

\section{DEPÓSITO AURÍFERO OURO ROXO}

O depósito Ouro Roxo compreende enxames de veios de quarto e pirita ( \pm calcopirita) cisalhados e/ou brechados, nos quais o conteúdo aurífero é normalmente proporcional à quantidade de sulfetos. Corpos mineralizados tubulares de quartzo, na forma de charuto, embora em menor abundância, também ocorrem na direção principal do cisalhamento (N-S). Os corpos mineralizados são controlados estruturalmente pela zona de cisalhamento Ouro Roxo-Canta Galo e compreendidos entre os setores do Ouro Roxo Norte, Médio e Sul.

Os veios e charutos mineralizados estão sempre envolvidos por um halo de alteração hidrotermal bem desenvolvido, normalmente proporcional à dimensão dos filóes e constituído principalmente por sericita + clorita + sulfeto (pirita) e minério disseminado. Os veios e charutos, juntamente com seus halos de alteração, formam corpos mineralizadas, normalmente ao longo da direção principal

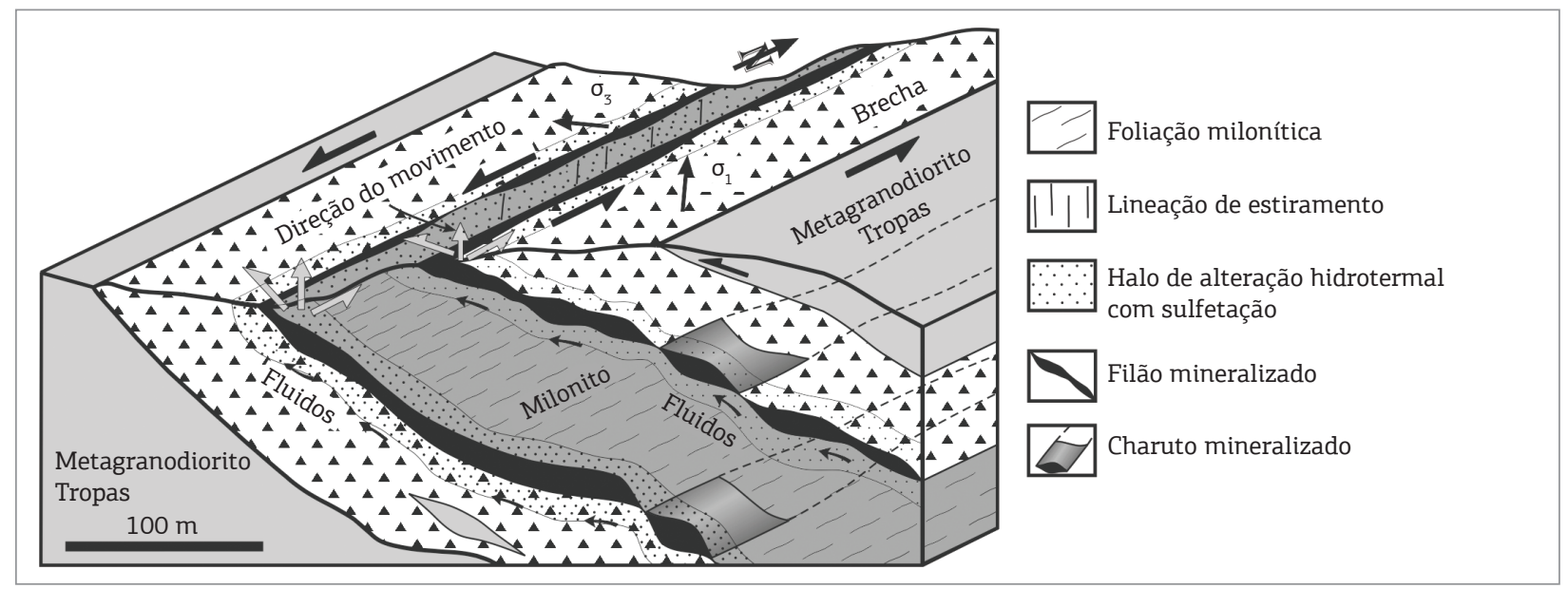

Figura 5. Bloco diagrama esquemático mostrando o controle estrutural dos filões e charutos mineralizados em zonas de transtensão da zona de cisalhamento Ouro Roxo-Canta Galo. 
do cisalhamento (N-S), com espessuras entre $10 \mathrm{~cm}$ e $1 \mathrm{~m}$ (Fig. 5). Além do quartzo, os corpos mineralizados contêm pirita e calcopirita e em menor proporção bismutinita, bismuto nativo, e ouro. Os principais minerais de ganga, em ordem de abundância, são clorita, sericita, carbonato e como minerais supergênicos ocorrem goethita, bornita, azurita e covelita.

A pirita é o mineral mais abundante depois do quartzo e é o sulfeto dominante, embora, localmente, a calcopirita chega a ser mais abundante que a pirita. Além disso, veios de pirita maciça com quartzo ocorrem excepcionalmente. Três geraçôes de pirita foram reconhecidas no sistema Ouro Roxo, sendo a primeira estirada (pirita1 magmática) que ocorre nos milonitos (Fig. 7A) e as outras duas hidrotermais. A primeira geração de pirita hidrotermal (pirita2) é representada por cristais anédricos que ocorrem nos veios e disseminados nos halos de alteração (Fig.7B). A segunda geração de pirita hidrotermal (pirita3) ocorre como cristais euédricos (Fig. 7C), exibindo seçôes quadradas, retangulares e triangulares, em vênulas tardias que cortam rochas hidrotermalizadas do halo de alteração. $\mathrm{O}$ ouro ocorre como diminutos cristais anédricos associados com bismutinita, ambos inclusos em pirita2 (Fig. 8A). Duas geraçóes de calcopirita foram reconhecidas nos veios mineralizados. A primeira geração (calcopirita1) ocorre normalmente como diminutos cristais xenomórficos associados com pirita2, os quais são comumente substituídos por covelita (Fig. 8B), bornita (Fig. 8C) e azurita. A segunda geração (calcopirita2) ocorre normalmente substituindo as bordas de cristais de pirita2 (Fig. 8A). A bismutinita ocorre nos veios de quartzo como cristais anédricos de coloração cinza azula$\mathrm{da}$, comumente inclusos em cristais de pirita2 e associados

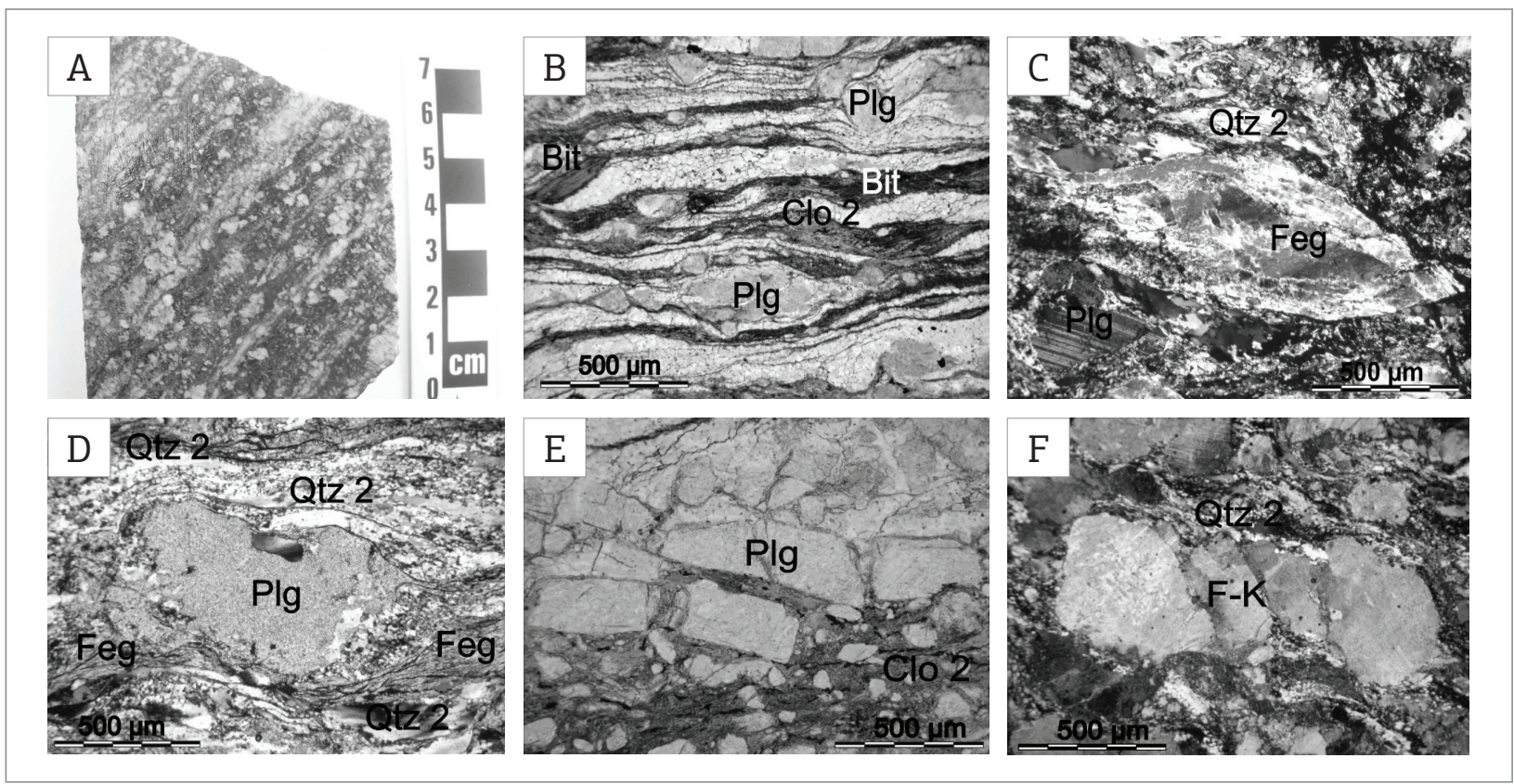

Figura 6. Feições microtexturais nos milonitos do depósito Ouro Roxo. Fotografia e fotomicrografia de foliação $C$ (A e B). Fotomicrografias de Micafish (C) em cristal de fengita (Feg), de porfiroclasto amendoado de plagioclásio com calda de recristalização e sombra de pressão (D) e de porfiroclasto de plagioclásio microboudinado (E) e de feldspato potássico ( $\mathrm{F}$ a K) microfalhado com deslocamento e rotação $(\mathrm{F})$.

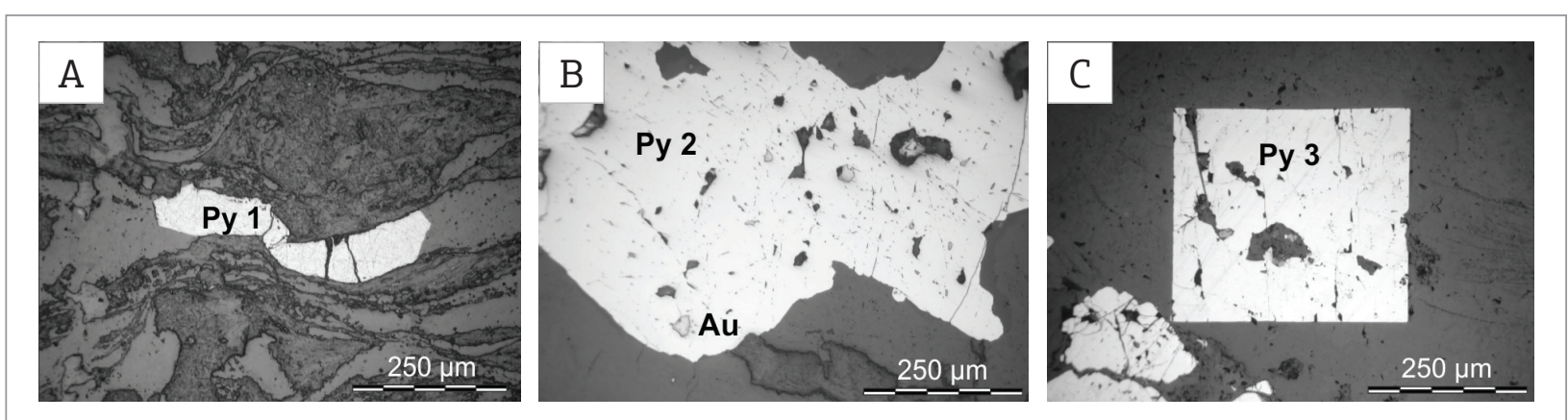

Figura 7. Gerações de pirita do depósito Ouro Roxo. Fotomicrografias de pirita1 magmática estirada (A), pirita2 anédrica hidrotermal (B) e pirita3 euédrica hidrotermal (C). 
com diminutos cristais de bismuto nativo de coloraçáo creme amarelada e textura rugosa. Esses cristais de Bi ocorrem normalmente nas bordas dos cristais de bismutinita, evidenciando um processo de substituição (Fig. 8A). Esta situação sugere que o Bi cristalizou em condiçóes de escassez de enxofre que foi consumido para formar a bismutinita.

O quartzo é o principal mineral da ganga. Sete geraçóes deste mineral foram definidas pelo estudo petrográfico no sistema Ouro Roxo, sendo a primeira estirada (quartzol magmático, Fig. 9A) e o quartzo microcristalino (neoformado) que ocorre nas sombras de pressão e augens, ao longo da foliação milonítica, a segunda geração (quartzo2, Fig. 9B). As outras cinco geraçôes de quartzo são hidrotermais. A primeira geração hidrotermal (quartzo3) corresponde a cristais precoces de hábito cristalino anédrico com bordas corroídas e extinção ondulante (Fig. 9C). Uma segunda geração hidrotermal (quartzo4) é representada por cristais subédricos com bordas marcadas por agulhas de turmalina, estando associados ao quartzo3 (Fig. 9C). A terceira geração hidrotermal (quartzo5) é caracterizada por cristais microcristalinos também envolvidos por agulhas de turmalina (Fig. 9C), indicando, provavelmente, um pulso de cristalizaçáo rápida da sílica. A quarta geração hidrotermal (quartzo6) corresponde a cristais euédricos com inclusôes de agulhas de turmalina (Fig. 9D). A quinta e última geração hidrotermal (quartzo7) é representada por vênulas de microcristais que cortam o minério sulfetado (Fig. 9E). Além do quartzo, clorita e fengita, ambos de terceira geração, e carbonato de segunda geração ocorrem na ganga.

\section{Alteração hidrotermal}

A circulação de fluidos em zonas de cisalhamento é um fenômeno amplamente reconhecido, responsável pela hidratação de rochas e pela deposição de elementos de interesse econômico, como ouro. De acordo com Sibson (1990), Cox, Etheridge \& Wall (1990) e Godard \& Evans (1995), entre outros, a extensa formação de filonitos e veios de quartzo durante o período de atividade de uma zona de cisalhamento evidencia que a pressão de fluidos nesta zona excedeu a pressão litostática, tal como observado na zona de cisalhamento Ouro Roxo-Canta Galo. A ocorrência de milonitos e brechas hidrotermais no depósito Ouro Roxo evidencia também que a atividade dos fluidos se situou entre a mesozona e a epizona. A circulação dos fluidos, controlada pela ZCOC, resultou não só na deposição do minério aurífero como também no processo de alteração hidrotermal que afetou as rochas hospedeiras dos corpos mineralizados, formando halos de alteração em volta dos mesmos.

Os metagranodioritos da Suíte Intrusiva Tropas que ficaram parcialmente preservados da atuação do processo cisalhante e alteração hidrotermal são as rochas encaixantes do sistema hidrotermal do depósito Ouro Roxo e sofreram apenas alteraçóes incipientes. Três tipos de alteraçôes foram reconhecidas nos metagranitoides encaixantes: cloritização, sericitização e carbonatação que afetaram essas rochas sem destruir completamente sua composição mineralógica e texturas originais. A cloritização afetou principalmente os minerais ferromagnesianos (biotita e anfibólio) do metagranodiorito, os quais foram substituídos pela clorita, chegando a formar pseudomorfos de clorita sobre o anfibólio ou biotita (Fig. 10A). A sericitização afetou os feldspatos, principalmente o plagioclásio, onde sua atuação se concentrou nas bordas dos cristais (Fig. 10C), enquanto que nos cristais de microclina a substituição ocorreu no

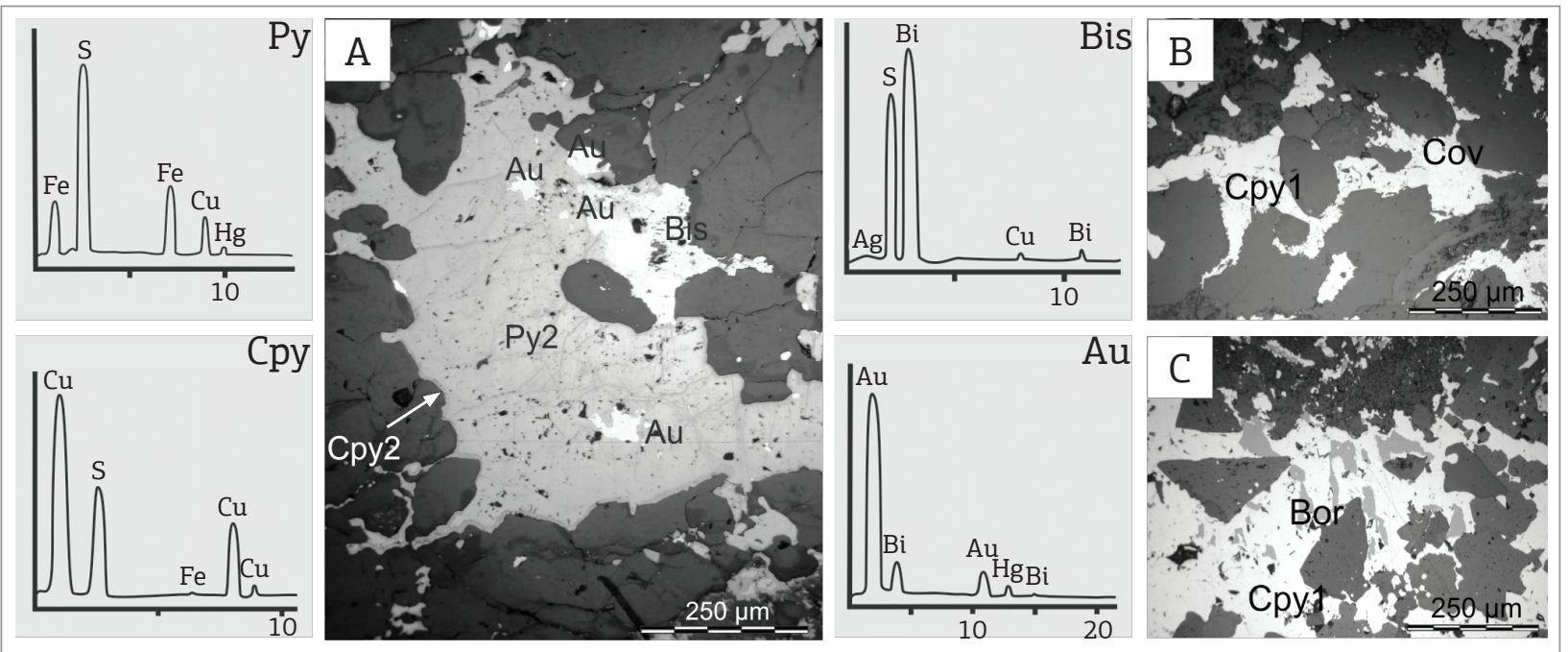

Figura 8. Cristal de pirita2 substituído nas bordas por calcopirita2 e com inclusões de ouro associado com bismutinita a bismuto nativo (A). Calcopirital substituída por covelita (B) e por bornita (C). Py: pirita; Cpy: calcopirita; Bis: bismutinita; Bor: bornita; Cov: covelita. 
núcleo desses cristais. A carbonatação atingiu a hornblenda e também o plagioclásio de forma corrosiva (Figs. 10E e F). O produto da alteração do plagioclásio normalmente é uma mistura de sericita, carbonato e epídoto.

A alteração hidrotermal nas rochas da zona de cisalhamento (protomilonitos, milonitos e ultramilonitos) foi nitidamente mais intensa e penetrativa quando comparada com a do metagranodiorito, refletindo o maior fluxo de fluidos nas rochas cisalhadas, com aumento da razão fluido/rocha. A associação do metamorfismo dinâmico (cisalhamento) com o processo hidrotermal resultou na completa obliteração da textura e minerais primários do metagranodiorito. A alteração hidrotermal não só se intensificou como também se diversificou. Além dos três tipos reconhecidos nos metagranodioritos, foram identificadas a silicificação e sulfetação, relacionadas aos corpos mineralizados hospedados nas rochas da zona de cisalhamento.

As alteraçôes fílica e propilítica são predominantes tanto nos milonitos como nos halos de alteração, ora predominando uma, ora outra. Estes dois tipos representam a continuação e intensificação da sericitização dos feldspatos e cloritização dos minerais ferromagnesianos reconhecidas nos protólitos (metagranodiorito). Nos milonitos, a alteração propilítica é caracterizada por cloritização proeminente, associada com carbonato e sericita subordinados, chegando a ser pervasiva (Fig. 10B). A clorita ocorre como diminutas lamelas, excepcionalmente ocorrendo como placas mais desenvolvidas. Corresponde à segunda geração (clorita2), sendo a cloritização dos minerais ferromagnesianos do metagranodiorito, a primeira geração (clorita1).
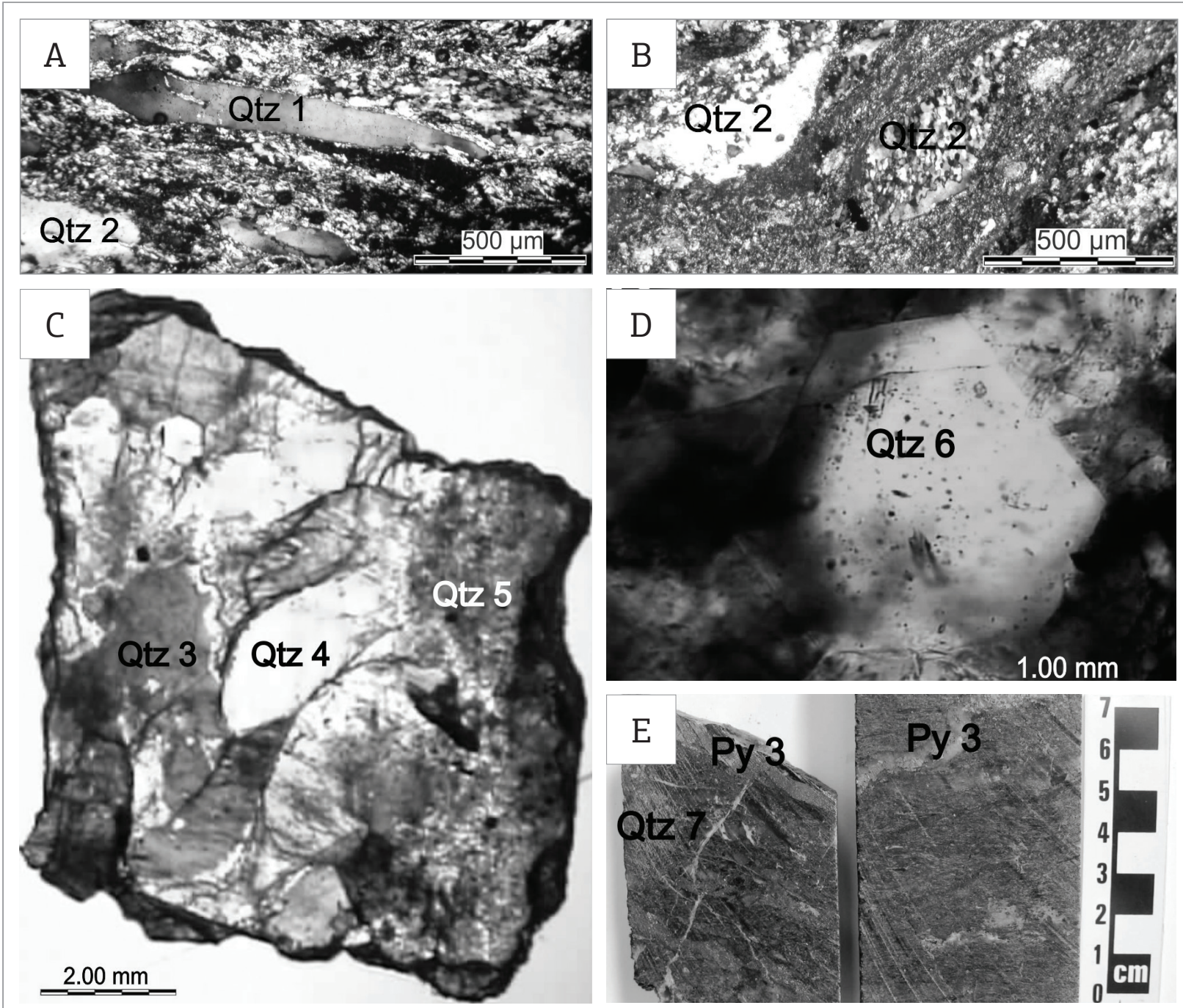

Figura 9. Gerações de quartzo (Qtz) do depósito Ouro Roxo. Fotomicrografias do quartzo1 magmático (A), quartzo2 microcristalino dos milonitos (B) e dos quartzo3, 4 e 5 (C) e quartzo6 hidrotermais (D). Fotografia de testemunho de sondagem do quarzo7 hidrotermal (E). 
A alteração fílica é caracterizada por sericitização expressiva nos milonitos, associada com quartzo microcristalino, diminutos cristais de carbonato e pirita, além de porfiroclastos de quartzo estirados e de plagioclásio amendoado. Alguns porfiroclastos de plagioclásio, embora alterados, mantiveram-se preservados da deformação, mas a maioria encontra-se em estado avançado de alteraçáo, normalmente como pseudomorfos de sericita (Fig. 10D). A sericita ocorre como finas lamelas ripiformes de fengita com pleocroismo verde amarelado ou azulado, marrom claro e róseo. Corresponde à segunda geração (fengita2), sendo a sericitização dos feldspatos do metagranodiorito, a primeira geração (sericita1).

Nos halos hidrotermais, a alteração foi mais intensa e sua paragênese se superpôs à paragênese metamórfica do cisalhamento, a qual foi obliterada pela paragênese hidrotermal, de tal modo que nos halos de alteração em volta dos filóes não há mais trama milonítica, a não ser uma sutil anisotropia reliquiar evidenciada por uma discreta orientação da mica branca (fengita) e clorita de terceira geração. Estes dois minerais constituem a base mineral dos halos de alteraçáo, ora predominando a clorita, ora a fengita.

A sulfetação ocorre associada à silicificação. Sulfetos ocorrem de forma maciça em veios de quartzo ou disseminados em massas de sericita e clorita nos halos de alteração e também em vênulas. As massas silicosas (silicificação) são bastante expressivas, ocorrendo como veios de quartzo mineralizados (Fig. 10G), como bolsóes e brechas de rochas silicosas, ou também como vênulas tardias. Vênulas de carbonato de terceira geração e de clorita de quarta geração são componentes menores que cortam os halos de alteração.
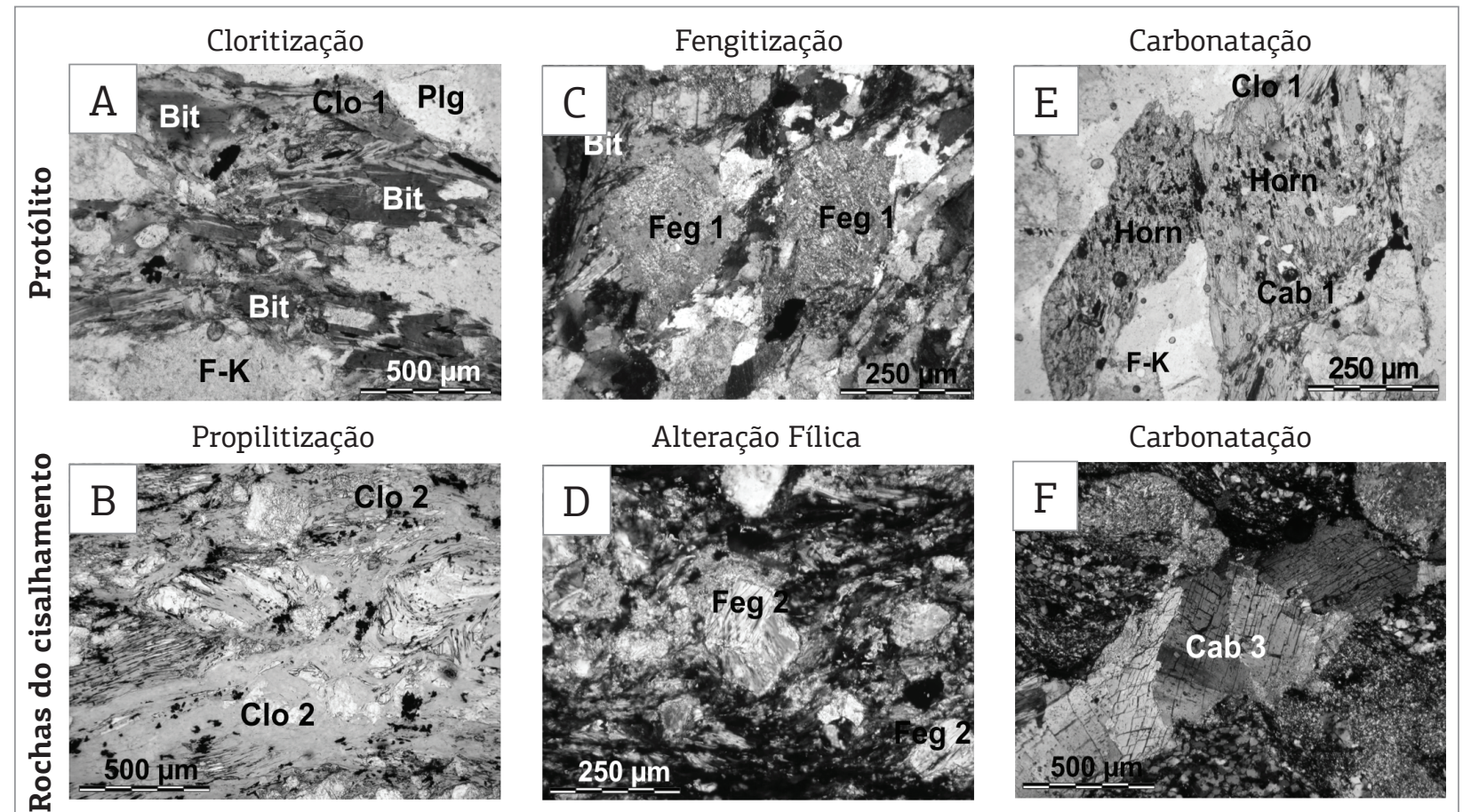

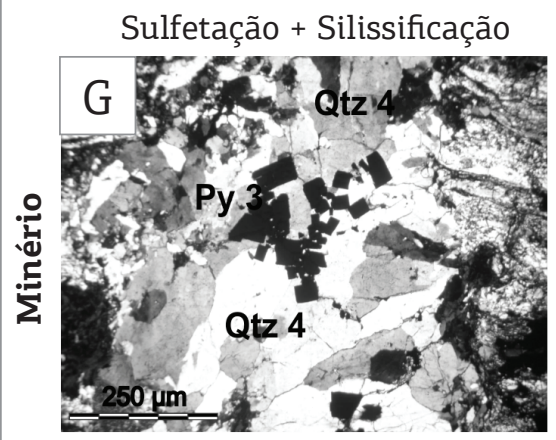

Figura 10. Alteração hidrotermal no sistema Ouro Roxo. Fotomicrografias mostrando cloritização (A), fengitização (C) e carbonatação (E) nos protólitos, além de propilitização (B), alteração fílica (D) e carbonatação (F) nas rochas do cisalhamento e sulfetação e silicificação no minério $(G)$. 


\section{Sequência paragenética do depósito Ouro Roxo}

Com base na composição mineralógica e relaçóes texturais das rochas do cisalhamento, dos veios mineralizados e dos halos de alteração hidrotermal, foi possível estabelecer uma sequência paragenética dos minerais metálicos, de ganga e secundários que ocorrem no depósito Ouro Roxo, conforme mostrado na Fig. 11. A atuação do intemperismo sobre a paragênese hidrotermal sulfetada gerou minerais supergênicos de cobre a partir da alteração da calcopirita1 (azurita, covelita e bornita), além de, provavelmente, ouro em corpos gossânicos que foi praticamente exaurido pela lavra garimpeira.

\section{GEOCRONOLOGIA}

Análises isotópicas de $\mathrm{Pb}$, em pirita do depósito aurífero Ouro Roxo, foram realizadas pelo método da lixiviação do $\mathrm{Pb}$, com o objetivo de obter a assinatura isotópica de $\mathrm{Pb}$ e a idade da mineralização. A metodologia $\mathrm{Pb}-\mathrm{Pb}$ baseia-se na desintegração radioativa em cadeia dos isótopos radioativos ${ }^{238} \mathrm{U} \mathrm{e}^{235} \mathrm{U}$, originando respectivamente dois isótopos urogênicos de $\mathrm{Pb}\left({ }^{206} \mathrm{~Pb}\right.$ e $\left.{ }^{207} \mathrm{~Pb}\right)$, e do ${ }^{232} \mathrm{Th}$ para o isótopo toriogênico ${ }^{208} \mathrm{~Pb}$. O ${ }^{204} \mathrm{~Pb}$ é usado como isótopo de referência para a avaliação dos acréscimos sofridos pelos outros três, pois ele é considerado relativamente estável, com

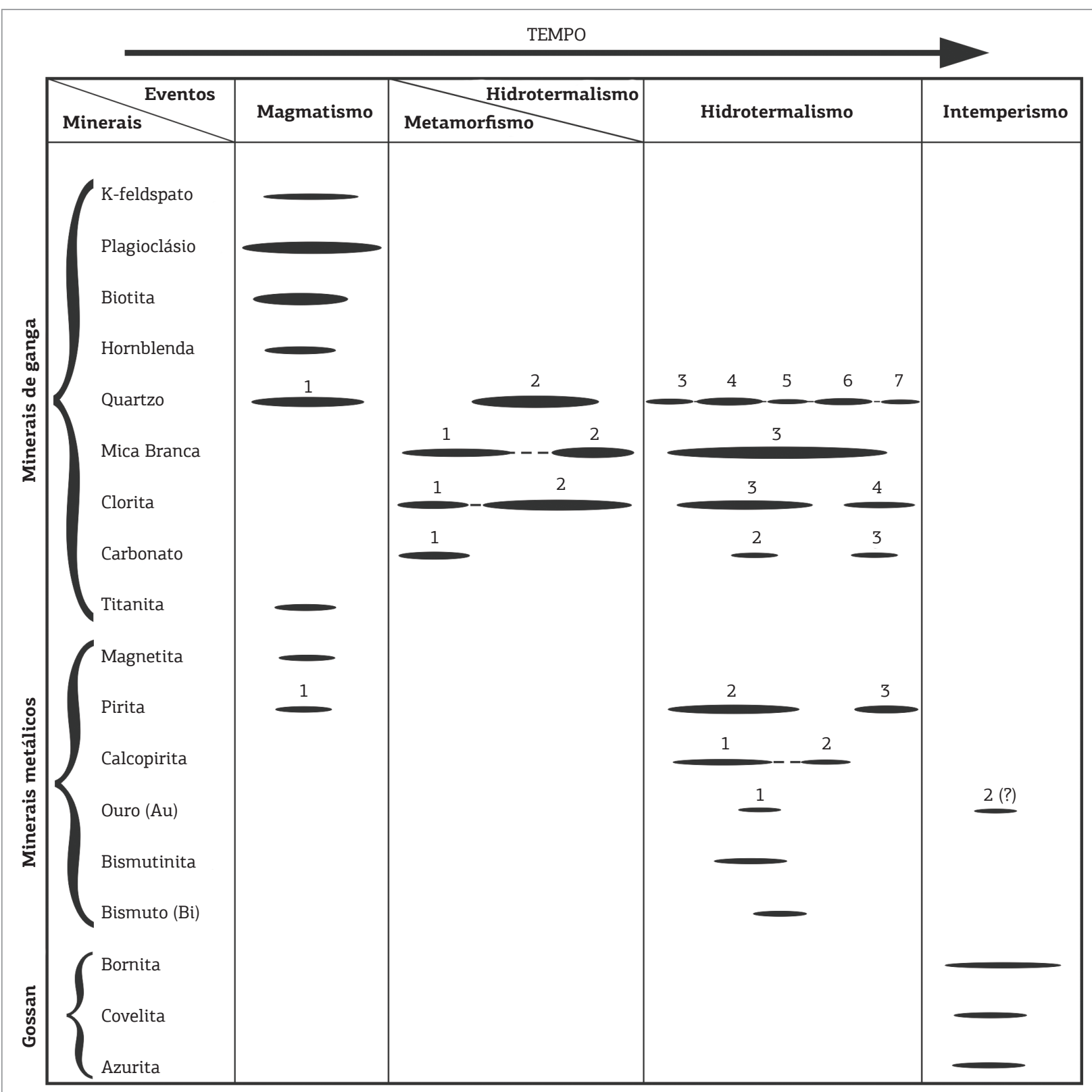

Figura 11. Diagrama paragenético dos minerais metálicos de ganga e secundários do depósito aurífero Ouro Roxo (Veloso 2011). 
uma meia-vida muito elevada $\left(t^{1 / 2}=1,4^{\prime} 10^{17}\right.$ anos, segundo Faure 1977) e sua abundância é considerada inalterada desde a formação da Terra ( $\mathrm{Pb}$ primordial). Desse modo, a técnica de lixiviação de $\mathrm{Pb}$ tem sido empregada em sulfetos, óxidos e outros minerais para a obtenção de idades isotópicas, por meio das razóes isotópicas ${ }^{206} \mathrm{~Pb} /{ }^{204} \mathrm{~Pb}$ e ${ }^{207} \mathrm{~Pb} /{ }^{204} \mathrm{~Pb}$ (Frei \& Kamber 1995). Segundo esses autores, se houver equilíbrio entre as fases e o sistema isotópico for fechado, é possível determinar a idade do material se as fraçóes lixiviadas do material analisado alinharem no diagrama ${ }^{207} \mathrm{~Pb} /{ }^{204} \mathrm{~Pb}$ versus ${ }^{206} \mathrm{~Pb} /{ }^{204} \mathrm{~Pb}$. A suposição de que a amostra de pirita analisada seja cogenética com o processo de alteração hidrotermal que deu origem ao depósito aurífero Ouro Roxo e que esse processo tenha evoluído em um sistema fechado, onde náo houve entrada ou saída de $\mathrm{U}, \mathrm{Th}, \mathrm{e} / \mathrm{ou} \mathrm{Pb}$ e ainda que somente o $\mathrm{Pb}$ medido nos dias atuais seja resultado da decomposição isotópica do $\mathrm{Pb}$ primordial aprisionado na época de formação do sulfeto, reúnem premissas importantes para a validação dos resultados alcançados pelo método empregado.

A análise isotópica de $\mathrm{Pb}$ da amostra de pirita proveniente de veios de quartzo mineralizados hospedados em milonitos do depósito Ouro Roxo, revelou razóes radiogênicas ${ }^{206} \mathrm{~Pb} /{ }^{204} \mathrm{~Pb}$ e ${ }^{207} \mathrm{~Pb} /{ }^{204} \mathrm{~Pb}$ muito elevadas, entre 21,12 e 24,19 e 16,25 e 16,59, respectivamente (Tab. 1, Fig. 12). Segundo McNaugton \& Groves (1996), composiçôes isotópicas de $\mathrm{Pb}$ muito radiogênicas, como é o caso do depósito Ouro Roxo, podem ser atribuídas ao decaimento in situ do $\mathrm{U}$. Outra possibilidade seria o $\mathrm{Pb}$ radiogênico ter sido derivado de $\mathrm{U}$ fixado na estrutura ou em inclusóes dentro dos sulfetos, ou mesmo de $\mathrm{Pb}$ mais radiogênico incorporado ao sulfeto a partir de uma fonte externa após a formação do sulfeto. Uma terceira hipótese a ser avaliada é a possibilidade de que os sulfetos tenham incorporado $\mathrm{Pb}$ radiogênico durante a sua precipitação, indicando a possibilidade de não terem evoluído em um sistema simples ou, mais provavelmente, que não tenham evoluído em um sistema completamente fechado.

O tratamento da composição isotópica da amostra analisada forneceu uma idade isocrônica de $1858 \pm 130 \mathrm{Ma}$,
MSWD 5.922 (Fig. 12), a qual, diante de seu erro ser elevado, representa apenas uma idade de referência para a mineralização do depósito Ouro Roxo (Veloso 2011). Frantz et al. (2005) obtiveram as idades de 1900 e $1880 \mathrm{Ma}$ para as rochas hospedeiras do depósito Ouro Roxo, interpretadas como idades do magmatismo (Suíte Tropas) e do hidrotermalismo, respectivamente. Tanto os dados geocronológicos apresentados por Veloso (2011), como aqueles de Frantz et al. (2005), sugerem que o hidrotermalismo que deu origem ao depósito Ouro Roxo não tem relação com o magmatismo Tropas que gerou os metagranodioritos encaixantes do sistema Ouro Roxo. Considerando que o hidrotermalismo deve ter sido contemporâneo com o cisalhamento, as idades obtidas para a cristalização do magmatismo Tropas (Frantz et al. 2005) e aquelas obtidas por Veloso (2011) para o hidrotermalismo indicam que o cisalhamento deve ter ocorrido em torno de 20 a 40 Ma de anos após a cristalização dos metagranitoides Tropas, aproximadamente na época do magmatismo Maloquinha.

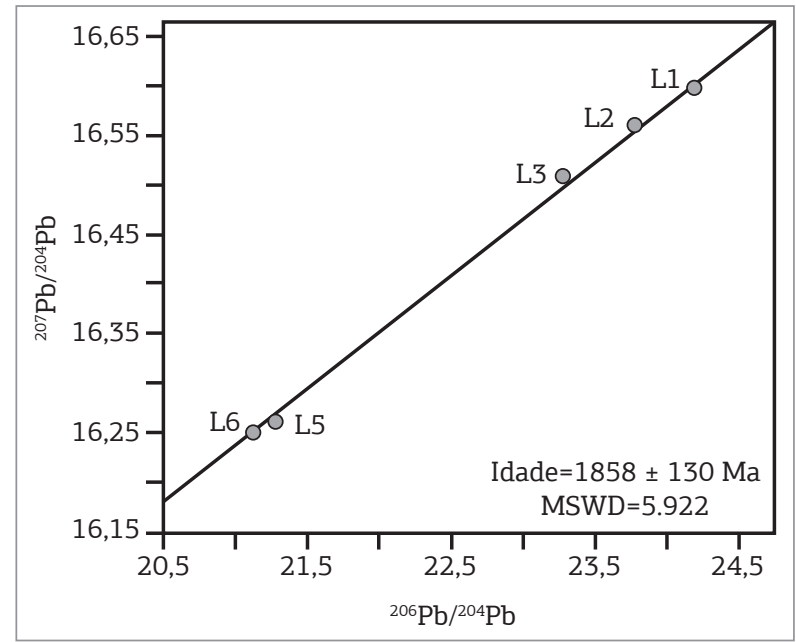

Figura 12. Diagrama das razões ${ }^{207} \mathrm{~Pb} / 204 \mathrm{~Pb}$ vs. ${ }^{206} \mathrm{~Pb} /{ }^{204} \mathrm{~Pb}$ para a amostra analisada de pirita, associada com quartzo3 e 4 dos veios hidrotermais do depósito Ouro Roxo.

Tabela 1. As seis razões ${ }^{206} \mathrm{~Pb} /{ }^{204} \mathrm{~Pb}$ e ${ }^{207} \mathrm{~Pb} /{ }^{204} \mathrm{~Pb}$ da amostra analisada de pirita, associada com quartzo3 e 4 dos

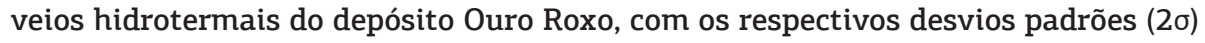

\begin{tabular}{l|c|c|c|c|c|c}
\hline Amostra & ${ }^{206} \mathbf{P b} /{ }^{204} \mathbf{P b}$ & $\mathbf{2 \sigma}$ & ${ }^{207} \mathbf{P b} /{ }^{204} \mathbf{P b}$ & $\mathbf{2 \sigma}$ & ${ }^{208} \mathbf{P b} /{ }^{204} \mathbf{P b}$ & $\mathbf{2 \sigma}$ \\
\hline L1 & 24,1902 & 0,0016 & 16,5960 & 0,0002 & 48,4719 & 0,0006 \\
\hline L2 & 23,7802 & 0,0003 & 16,5589 & 0,0002 & 47,8829 & 0,0007 \\
\hline L3 & 23,2799 & 0,0004 & 16,5061 & 0,0004 & 47,1272 & 0,0013 \\
\hline L4 & 23,1596 & 0,0002 & 16,5027 & 0,0001 & 46,9983 & 0,0004 \\
\hline L5 & 21,2788 & 0,0003 & 16,2585 & 0,0004 & 43,9580 & 0,0010 \\
\hline L6 & 21,1254 & 0,0004 & 16,2492 & 0,0003 & 43,7493 & 0,0009 \\
\hline
\end{tabular}




\section{CONCLUSÕES}

A integração dos dados geológicos e petrográficos permitem definir o depósito Ouro Roxo como um sistema hidrotermal filoneano hospedado em metagranitoides e controlado estruturalmente, com as seguintes características: as rochas encaixantes do sistema hidrotermal são metagranodioritos e metatonalitos paleoproterozoicos calcioalcalinos e oxidados da Suíte Intrusiva Tropas, típicos de arco magmático; as rochas encaixantes foram afetadas por uma zona de cisalhamento obliqua dúctil-rúptil sinistral que transformou os granitoides em uma sequência intercalada de milonitos e brechas hidrotermalmente alterada de profundidade média a rasa, típica da interface mesozona-epizona; os corpos mineralizados ocorrem em zonas de transtensão do cisalhamento, como enxames de veios e charutos epigenéticos de quartzo ao longo da direção principal do cisalhamento (NNE-SSW), envolvidos por halos de alteração com mineralização disseminada; o minério é sulfetado com associação metálica $\mathrm{Au}-\mathrm{Cu}-\mathrm{Bi}$. A pirita é o sulfeto dominante nos corpos mineralizados e o ouro ocorre associado com a segunda geração de pirita (pirita2 sin-cisalhamento), juntamente com calcopirita, bismutinita e bismuto nativo; os veios estão invariavelmente envolvidos por halos de alteração hidrotermal, estabelecidos na sequência de milonitos e brechas, formando um sistema filoniano de dezenas de metros de espessura. Além da silicificação e sulfetação, mais concentradas nos veios e charutos, três tipos de alteraçáo se destacam com intensidade crescente das rochas encaixantes para os corpos mineralizados: a) alteração propilítica (clorita + fengita + carbonato), com quatro geraçôes de clorita, sendo a última venular; b) alteração fílica (fengita + quartzo + pirita), com três geraçôes de fengita; c) carbonatação com três geraçóes de carbonato. Além do quartzo magmático e do quartzo microcristalino dos milonitos, ocorrem cinco geraçóes de quartzo filoniano hidrotermal, sendo a última em forma de vênulas. $\mathrm{O}$ minério está relacionado principalmente com quartzo4; os dados geocronológicos obtidos para o sistema Ouro Roxo não sustentam uma relação genética entre o depósito aurífero e os granitoides da Suíte Tropas, sendo estes últimos 20 a $30 \mathrm{Ma}$ mais antigos que o depósito; as características geológicas, petrográficas e geocronológicas do depósito Ouro Roxo são compatíveis com o modelo orogênico da interface mesozona-epizona de Groves et al. (1998).

\section{AGRADECIMENTOS}

Ao Instituto de Geociências da UFPA pelo suporte técnico; ao Conselho Nacional de Desenvolvimento Científico e Tecnológico (CNPq) pela concessão da bolsa de mestrado à primeira autora; ao Prof. Jean-Michel Lafon pela contribuição na interpretação dos dados isotópicos; aos pesquisadores Márcio Dias Santos e Raimundo Netuno N. Villas do grupo de pesquisa de geologia econômica da UFPA, os quais estiveram sempre dispostos a me ouvir, para que eu pudesse tirar minhas próprias conclusóes sobre este trabalho. Este artigo é uma contribuição para o Instituto Nacional de Ciência e Tecnologia de Geociências da Amazônia (GEOCIAM).

\section{REFERÊNCIAS}

Almeida M.E., Brito M.F.L., Ferreira, A.L., Monteiro M.A.S. 2000. Geologia e Recursos Minerais da Folha Mamãe Anã (SB.21-V-D). Estados do Amazonas e Pará. Nota explicativa. Projeto Especial Província Mineral do Tapajós (PROMIM). Brasília, CPRM, escala 1:250.000.

Bahia R.B.C. \& Quadros M.L.E.S. 2000. Geologia e recursos minerais da Folha Caracol (SB-21-X-C). Estado do Pará. Nota explicativa. Projeto Especial Província Mineral do Tapajós (PROMIM). Brasília: CPRM, escala 1:250.000

Bizzinella G.A., Santiago A.F., Santos A., Borges F.R., Souza F.J.C., Godoy H,K., Yamaguti H.S., Oliveira J.R., Oliveira LR. 1980. Projeto TapajósSucunduri, Relatório Final, partes I e II. Manaus: DNPM/CPRM, V. Ia e Ib.

Cox S.F., Etheridge M.A., Wall V.J. 1990. Fluid pressure regimes and fluid dynamics during deformation of low-grade metamorphic terrains implications for the genesis of mesothermal gold deposits. In: Robert F., Sheahan P.A., Green S.B. (eds.) Greenstone gold and crustal evolution. NUNA conference, Geological Association of Canada, p. 46-53.

Dreher A.M., Vlach S.R.F., Martini S.L. 1998. Adularia associated with epithermal gold veins in the Tapajós Mineral Province, Pará State, northern Brazil. Revista Brasileira de Geociências, 28(3):397-404.
Faure G.1977. Principles of isotope geology. London, J. Wiley \& Sons, 464 p.

Faraco M.T.L., Carvalho J.MA., Klein E.L. 1997. Carta metalogenética da Província Aurífera do Tapajós. In: Costa M.L. \& Angélica R.S. (eds.). Contribuições à Geologia da Amazônia. Belém, SBG-NO, p. 423-437.

Ferreira A.L., Almeida M.E., Brito M.F.L., Monteiro M.A.S. 2000. Geologia e recursos minerais da Folha Jacareacanga (SB.21-Y-B), Estados do Amazonas e Pará, Nota explicativa, Projeto Especial Província Mineral do Tapajós. Manaus, PROMIM Tapajós/CPRM, escala 1: 250.000. 1 CD-ROM.

Frantz J.C., Marques J.C., Almeida B.S., Santos J.O. 2005. A mineralização cupro-aurífera do prospecto do Ouro Roxo, distrito aurífero do Tapajós - caracterização do depósito (fluidos, mineralogia e relações isotópicas). In: Simpósio Brasileiro de Metalogenia 1 CD-Rom.

Frei R. \& Kamber B.S. 1995. Single mineral lead dating. Earth Planetary Science Letters, 129:261-268

Goddard J.V. \& Evans J.P. 1995. Chemical changes and fluid-rock interaction in faults of crystalline thrust sheets, northwestern Wyoming USA. Journal of Structural Geology, 17(4):533-547. 
Groves D.I., Goldfarb R.J., Gebre-Marian M., Hagemann S.G., Robert F. 1998. Orogenic gold deposits: a proposed classification in the context of their crustal distribution and relationship to other gold deposit types. Ore Geology Reviews, 13:7-27.

Jacobi P. 1999. The discovery of epithermal Au-Cu-Mo Proterozoic deposits in the Tapajós Province, Brazil. Revista Brasileira de Geociências, 29(2):277-279.

Juliani C., Rye R.O., Nunes C.M.D., Snee L.W., Corrêa Silva R.H., Monteiro L.V.S., et al. 2005. Paleoproterozoic high-sulfidation mineralization in the Tapajós gold province, Amazonian Craton, Brazil: geology, mineralogy, alunite argon age, and stable-isotope constraints. Chemical Geology, 215:95-125.

Klein E.L. \& Vasquez M.L. 2000. Geologia e recursos minerais da Folha Vila Riozinho - SB.21-Z-A. Estado do Pará Escala 1:250.000. Nota explicativa. Projeto Especial Província Mineral do Tapajós. PROMIN Tapajós/CPRM, Brasília. 1 CD-Rom.

Klein E.L., Vasquez M.L., Rosa-Costa L.T., Carvalho J.M.A. 2002. Geology of paleoproterozoic gneiss- and granitoid-hosted gold mineralization in southern Tapajós Gold Province, Amazonian Craton, Brazil. International Geology Review, 44:544-558.

McNaughton N.J. \& Groves D.I. 1996. A review of Pb-isotope constraints on the genesis of lode-gold deposits in the Yilgarn Craton, Western Australia. Journal of the Royal Society of Western Australia, 79:123-129.

Park R.G. 1988. Geological structure and moving plates. Glasgow: Blackie. 337p.

Ricci P.S.F., Santos A., Klein E.L., Jorge João X.S., Martins R.C. 1999. Suíte Intrusiva Creporizão - Província Tapajós: proposta e critérios de definição. In: Simpósio de Geologia da Amazônia, 6. Anais, p. 519-522.

Santos D.B., Fernandes P.E.C.A., Dreher A.M., Cunha F.B., Basei M.A.S., Teixeira J.B.G. 1975. Geologia - Folha SB.21 Tapajós. In: Projeto RADAM, Levantamento de recursos naturais, 7. Rio de Janeiro, DNPM, p. 15-99.

Santos J.O.S., Hartmann L.A., Gaudette H.E., Groves D.I., McNaughton N., Fletcher I.R. 2000. A new understanding of the Provinces of the Amazon Craton based on integration of field mapping and $\mathrm{U}-\mathrm{Pb}$ and Sm-Nd geochronology. Gondwana Research, 3(4):453-488.

Santos J.O.S., Groves D.I., Hartmann L.A., Moura M.A., McNaughton N.J. 2001. Gold deposits of the Tapajós and Alta Floresta Domains,
Tapajós-Parima orogenic belt, Amazon Craton, Brazil. Mineralium Deposita, 36:278-299.

Santos J.O.S., Van Breemen O.B., Groves D.I., Hartmann L.A., Almeida M.E., McNaughton N.J., et al. 2004. Timing and evolution of multiple Paleoproterozoic magmatic arcs in the Tapajós Domain, Amazon Craton: constraints from SHRIMP and TIMS zircon, baddeleyite and titanite U-Pb geochronology. Precambriam Reserch, 131:73-109.

Santos J.O.S., Hartmann L.A., Faria M.S.G., Riker S.R., Souza M.M., Almeida M.E., McNaughton N.J. 2006. A compartimentação do Craton Amazonas em províncias: avanços ocorridos no período 2000-2006. In: SBG-NO, Simpósio de Geologia da Amazônia, 9 , Belém, CD-Rom.

Sibson R.H. 1977. Faults and fault rock mechanism. Journal of the Geological Society, 133(3):191-213

Sibson R.H. 1990. Fault structure and mechanics in relation to greenstone gold deposits. In: Robert F., Sheahan P.A., Green S.B. (eds.) Greenstone Gold and Crustal Evolution. NUNA conference, Geological Association of Canada, p. 54-60.

Souza W.S.P. 2007. O depósito de Ouro Roxo. In: I Simpósio Província Aurífera do Tapajós. Itaituba, Adimb, CD-Rom.

Tassinari C.C.G \& Macambira, J.B.M., 1999. Geochronologial provinces of the Amazon Craton. Episodes, 22(3): 174-182.

Vasquez M.L. \& Klein E.L. 2000. Geologia e recursos minerais da Folha Rio Novo - SB.21 - Z- C, Estado do Pará. Nota explicativa. Projeto Especial Província Mineral do Tapajós. Brasília, CPRM, PROMIM Tapajós, escala 1:250.000. 1 CD-Rom.

Vasquez M.L., Klein E.L., Ricci P.S.F. 2001. Granitóides pós-colisionais da porção leste da Provincia Tapajós. In: SBG, Simpósio de Geologia da Amazônia. 1 CD-Rom.

Veloso A.S.R., Santos M.D., Santos W.P., Snee L.W. 2008. Relação entre a mineralização aurífera do depósito Ouro Roxo e a zona de cisalhamento Ouro Roxo-Canta galo, Província Tapajós, Pará. In: SBG, Congresso Brasileiro De Geologia. 44, Anais, p.64.

Veloso A.S.R. 2011. Geologia e metalogênese do depósito aurífero Ouro Roxo, província tapajós, Jacareacanga-PA. Dissertação de Mestrado, Instituto de Geociências, Universidade Federal do Pará, Belém, 105 p.

Arquivo digital disponível on-line no site www.sbgeo.org.br 